\title{
ACUTE PHASE PROTEIN RESPONSE IN COWS WITH STAPHYLOCOCCUS AUREUS SUBCLINICAL MASTITIS
}

\author{
KOVAČEVIĆ FILIPOVIĆ MILICA*, STEVANOVIĆ JELKA*, STEVANOV PAVLOVIĆ MARIJA**, \\ DEBELJAK MARTAČIĆ JASMINA***, KNEŽEVIĆ MILIJANA*, MIJAČEVIĆ ZORA* \\ and BOŽIĆ TATJANA* \\ *University of Belgrade, Faculty of Veterinary Medicine, Serbia \\ **"DSP Chromatography" d.o.o., Belgrade, Serbia \\ ***Institute for Medical Research, University of Belgrade, Serbia \\ (Received 2nd November 2009)
}

Inflammation at a local and systemic level is a complex process that involves the synthesis of acute phase proteins (APPs) with multiple functions in the regulation of the inflammatory process itself. The aim of this work was to define local and systemic APPs response induced by natural Staph. aureus subclinical infection of the mammary gland in dairy cows with a different number of quarters involved. Midlactation dairy cows $(n=30)$ were devided into three groups. First group were cows with bacteriologically negative milk samples (BN group), second group were cows with one quarter infected with Staph. aureus (SaQ1) and third group were cows with two quarters infected (SaQ2). Milk samples were analyzed for inflammation indicators: serum amyloid $A$ (SAA) and somatic cell count (SCC). Serum samples where analyzed for SAA, haptoglobin (Hp), ceruloplasmin (Cp) and albumin concentration. Also, complete blood count (CBC) was done. SCC and $S A A$ increased in quarter milk samples, being lowest in the BN group and highest in the SaQ2 group. In serum samples, SAA, Hp, Cp and albumin concentrations were significantly higher only in the SaQ2 group comparing with BN group. The leukocyte number, as well as hemoglobin concentration were in the physiological range in all three groups of cows. These results confirm that the magnitude of tissue injury has an impact on APPs concentration. They also demonstrate that cows having Staph. aureus sublinical infections of two mammary quarters have a more pronounced systemic APP response than cows with only one quarter involved.

Key words: serum amyloid A, haptoglobin, ceruloplasmin, Staph. aureus, subclinical mastitis

\section{INTRODUCTION}

Inflammation is complex biological response to tissue injury provoked with infective or non infective harmful agents. Depending on the magnitude of tissue 
damage, the body non-specific reaction could be either local or local and systemic. Local reaction of injured tissue leads to local vasodilatation, exudation and cellular influx with two main functions: removal of harmful agents and initiation of the healing process. Systemic reactions also called acute phase response (APR), comprise metabolic, immunologic and neural responses evolutionary developed with the aim to fight against acute disturbances in body homeostasis. If the presence of harmful stimulus is prolonged the pattern of acute phase reactions is modified, some processes are attenuated while others are accentuated, together leading to the development of chronic inflammation (Medzhitov, 2008). In ruminant pathology, chronic subclinical inflammation is of major interest as it leads to a decrease in animal productive and reproductive performances. One of the diseases of major interest to dairy industry is Staphylococcus aureus (Staph. aureus) provoked subclinical mastitis. Local reaction is characterized with a rise of granulocyte and macrophage number in milk (termed somatic cells), as well as changes in milk composition (Barkema et al., 2006). The extent and consequence of systemic reaction to Staph. aureus provoked subclinical mastitis is not completely understood and defined.

A prominent biochemical event in both acute and chronic inflammatory systemic reaction, is the change in plasma concentration of multiple acute phase proteins (APPs). Due to intensified synthesis by hepatocytes, plasma concentrations of the majority of APPs increase (positive APPs), while the concentration of others decrease (negative APPs). Negative APPs are less described than positive ones. Changes of APPs concentrations are widely discussed in the context of complex modulation of inflammatory response (Uhlar and Whitehead, 1999). The main interest of APPs research in veterinary medicine is related to the fact that measurement of APRs provides a mean to assess the innate immune system response to disease. This is of major importance knowing that leukocyte response in ruminants is not sensitive to inflammation.

In ruminants, positive APPs considered effective markers of inflammation are haptoglobin $(\mathrm{Hp})$ and serum amyloid $\mathrm{A}(\mathrm{SAA})$. Plasma of healthy cows has low concentrations of these proteins, but upon stimulation with proinflammatory cytokines, the liver increases their production rate between 10 an 1000 times. Literature data about ceruloplasmin (Cp) being an acute phase protein in bovines are contradictory (Conner et al., 1989; Tabrizi et al., 2008; Nazifi et al., 2009) and its characterization needs more investigation.

Recently, the mammary isoform of SAA was identified (McDonald et al., 2001), and it was established that mastitis of different etiology provoke synthesis of both, mammary and plasma SAA isoforms (Jacobsen et al., 2005). Increased milk SAA concentration is due to the presence of both isoforms, as the plasma isoform exudates in the milk of the inflamed mammary gland (Jacobsen et al., 2005). Also, the rise in plasma SAA and $\mathrm{Hp}$ was documented in experimentally provoked Staph. aureus subclinical mastitis (Eckersall et al., 2006) and a dose dependent SAA response was documented when multiple intrammamary Staph. aureus (Eckersall et al., 2006) or intravenous lipopolysaccharide injections have been applied (Jacobsen et al., 2004). Literature data on systemic and local APP reactions when one or multiple quarters are inflamed have not been reported yet. 
The present investigation was undertaken to define local and systemic APPs response induced by natural Staph. aureus subclinical infection of the mammary gland in dairy cows with a different number of quarters involved.

\section{MATERIAL AND METHODS}

\section{Sampling}

The study has been performed on a commercial dairy farm in January average daily temperature $+4^{\circ} \mathrm{C}$. Blood and milk samples were obtained from 30 clinically healthy midlactation, multiparus (between parities two and five), Holstein cows (150 10 days of lactation) with no signs of inflammation of the mammary glands. The average milk production on the farm was $4000 \mathrm{~L}$ per year. Milking frequency was twice a day. The collection of samples was done during the routine mammary gland health screening procedure with California mastitis test that is performed monthly. Teats were routinely disinfected with $70 \%$ ethanol. Before sample collection, the first milk jets were discarded and approximately $15 \mathrm{~mL}$ of milk was aseptically collected from each udder quarter by hand milking before the normal afternoon milking. All 120 milk samples were divided in three parts: one part was used for somatic cells count (SCC), the second part for bacteriology and the third part for the determination of SAA concentration and isoforms. This third part was centrifuged at $4^{\circ} \mathrm{C}$ for 12 minutes at $1600 \times \mathrm{g}$ to obtain skimmed milk samples that were also stored at $-20^{\circ} \mathrm{C}$ until analysis. Blood serum was separated $2 \mathrm{~h}$ after venepuncture ( $v$. jugularis), centrifuged, and stored at $-20^{\circ} \mathrm{C}$ until analysis. Blood for complete blood count was taken in commercial tubes with anticoagulant (BD Vacutainer, BD-Plymouth, UK).

\section{Somatic cell count and bacteriology}

Mammary gland health was estimated by means of SCC and bacteriology. SCC is accepted as the dairy industry's standard indicator in the diagnosis of subclinical mastitis. SCC in the milk samples was measured on Fossomatic 360 (Foss Electric, Hillerad, Denmark).

Samples for bacteriology were processed according to Tolle et al., (1977). Briefly, aseptically collected milk samples were plated onto blood agar plates and incubated 24 hours at $37^{\circ} \mathrm{C}$. White colonies with a hemolytic zone characteristic for Gram-positive cocci were tested for catalase and coagulase activity. Catalase positive and coagulase positive cocci were marked as Staph. aureus. Milk samples without bacterial growth detected were designated as bacteriologically negative.

\section{Allotment into groups}

Bacteriologically negative $(B N)$ group $(n=7)$ : It was previously shown that due to a variation in the number of bacteria present at different time points during mastitis,, if the quarters are examined only once (Sears et al., 1990) negative bacteriological results are common. As we did not perform multiple consecutive bacteriological tests, as a supplemental parameter to estimate mammary gland health, we used SCC. Djabri et al. (2002), in their meta-analysis on quarter milk 
SCC in infected cows, as well as other authors reviewed by Pyörälä et al. (2003), reported that healthy quarters had SCC less than 100000 . Using this criteria we identified seven animals with bacteriologically negative milk samples from all quarters, and a very low SCC (under 35000 ). Further, two milk samples per animal (14 samples) were randomly chosen for determination of SAA concentration.

Staph. aureus positive group with one quarter infected - (SaQ1) group $(n=10)$ : Ten cows with only one quarter milk sample positive for Staph. aureus were detected (10 quarters). These samples had more than 500000 SCC, and thus were defined as subclinical mastitis samples (IDF, 1971). They also had been chosen for determination of SAA concentration. The remaining 30 bacteriologically negative milk samples were not included in this study.

Staph. aureus positive group with two quarters infected - (SaQ2) group $(n=10)$ : Four cows with two quarter milk samples positive for Staph. aureus were detected (20 quarters). These samples had more than 500000 SCC and were also defined as subclinical mastitis samples (IDF, 1971). They also have been chosen for determination of SAA concentration. The remaining quarters that were not infected were not included in this study.

Except Staph. aureus, Microccocus spp. and Corynebacterium bovis were detected in milk samples of 3 cows. These cows were eliminated from further studies.

Complete blood count, serum amyloid A, haptoglobin, ceruloplasmin and albumin concentration

Measurement of complete blood count was done on the automatic analyzer (Diatron, France).

The concentrations of SAA in serum and milk samples were determined using a commercially available sandwich ELISA kit (Tridelta Development Ltd, Greystones Co, Wickow, Ireland) according to the manufacturer's instructions. It was previously confirmed that both plasma and milk SAA isoforms could be detected using the specified test kit (Jacobsen et al., 2005). Serum samples were initially diluted 1:500 and milk samples 1:50, and further diluted until the range of the standard curve values was obtained. A sensitive ELISA kit (Tridelta Development Ltd, Greystones Co, Wickow, Ireland) was used to measure $\mathrm{Hp}$ in serum. The oxidase activity of $\mathrm{Cp}$ in serum was obtained using a colorimetric enzyme assay (Holmberg et al., 1951). Albumin concentration was determined using the colorimetric procedure with bromcresolgreen (McPherson and Everard, 1972) on spectrophothometar Specol M-40, A-637nm (Karl Zeiss Jena, Germany). All samples were tested in duplicate.

Statistical analyses

Results were presented as the mean \pm standard deviation (SD). Statistical significance of differences between two groups was determined by the two-tailed Student's t-test. Correlation between analyzed parameters was tested by linear regression. Differences with P-value of $<0.05$ were considered significant. All statistical analyses were carried out in Microsoft Excel software. 


\section{RESULTS}

In the milk samples taken from the BN group the number of somatic cells was under $0.035 \times 10^{6} / \mathrm{mL}$ (Figure $1 \mathrm{~A}$ ). On the contrary, in quarter milk samples from mammary glands of SaQ1 and SaQ2 group cows, SCC was significantly higher. Quarter milk samples contained on average $1.5 \times 10^{6}$ cells $/ \mathrm{mL}$ in SaQ1 group and $2.5 \times 10^{6}$ cells/mL in SaQ2 group (Figure 1A). Although SCC was higher when two quarters were infected comparing to one quarter infection, the difference was not significant (Figure 1A). SAA concentration was low (in average $1.7 \mu \mathrm{g} / \mathrm{mL}$ ) in milk samples from BN group and increased significantly with the number of quarters involved, being $24.4 \mu \mathrm{g} / \mathrm{mL}$ and $103 \mu \mathrm{g} / \mathrm{mL}$ in SaQ1 and

SaQ2 group, respectively (Figure $1 \mathrm{~B}$ ). Figures $1 \mathrm{~A}$ and $1 \mathrm{~B}$ show that $\mathrm{SCC}$ increased parallel to milk SAA concentration.

A

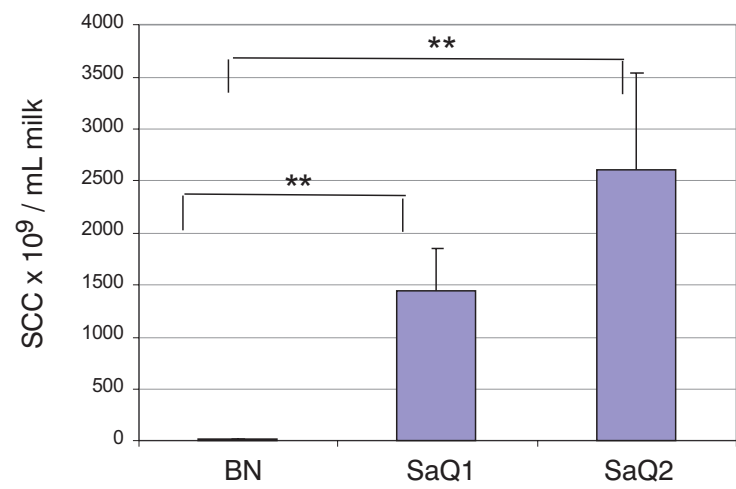

B

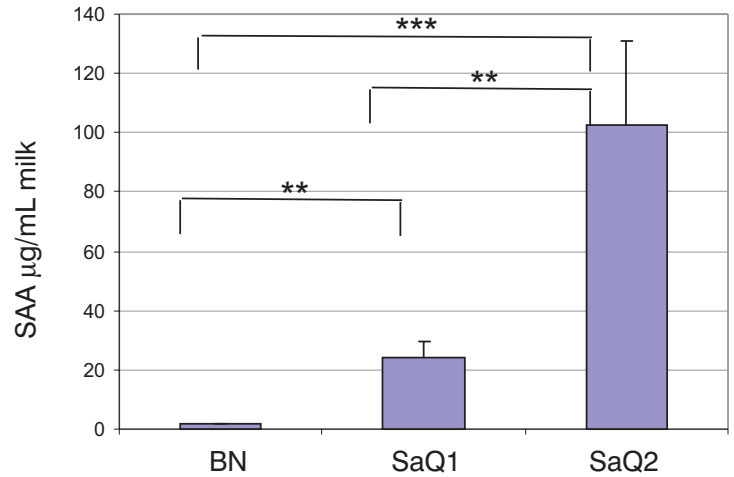

Figure 1. The response (mean $\pm S D$ ) of $A$ ) somatic cell count (SCC) and B) Serum amyloid A (SAA) in milk samples from cows with all quarter samples bacteriologically negative (BN group), one quarter infected with Staph. aureus (SaQ1 group) and two quarters infected with Staph. aureus (SaQ2 group) 
Serum amyloid A concentration in serum samples from BN group, was under $20 \mu \mathrm{g} / \mathrm{mL}$. Serum amyloid A concentration in serum samples from SaQ1 group was higher, yet, not significantly (Figure 2A). Further on, five times higher values were detected in the sera from SaQ2 group cows (Figure 2A). Haptoglobin concentration in sera from $B N$ and $S a Q 1$ group of cows was equal $(0.04 \mathrm{mg} / \mathrm{mL})$. A significant, 10 fold increase $(0.4 \mathrm{mg} / \mathrm{mL}$ ) was detected in SaQ2 group (Figure 2B).

A

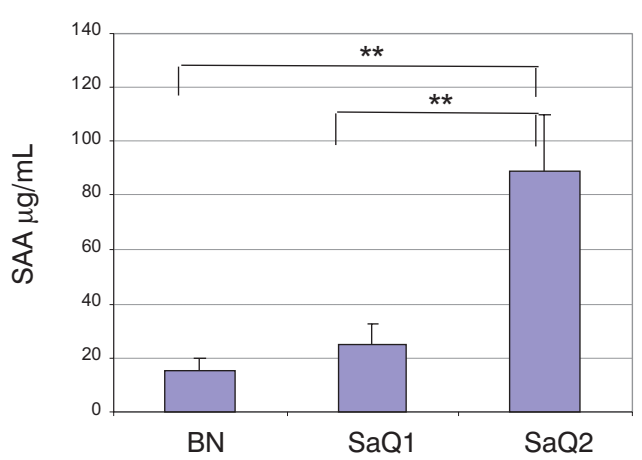

B

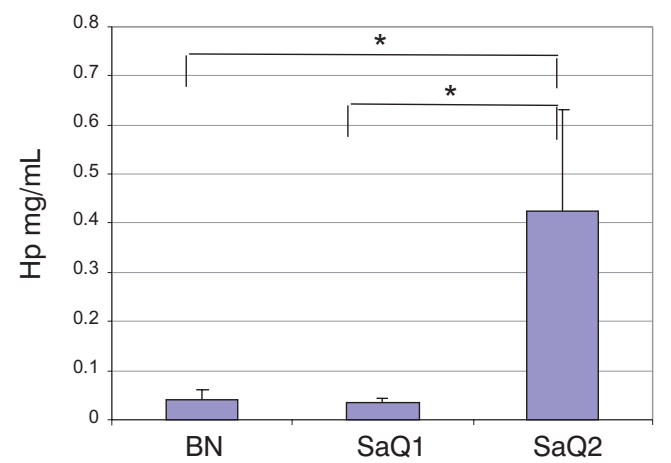

C

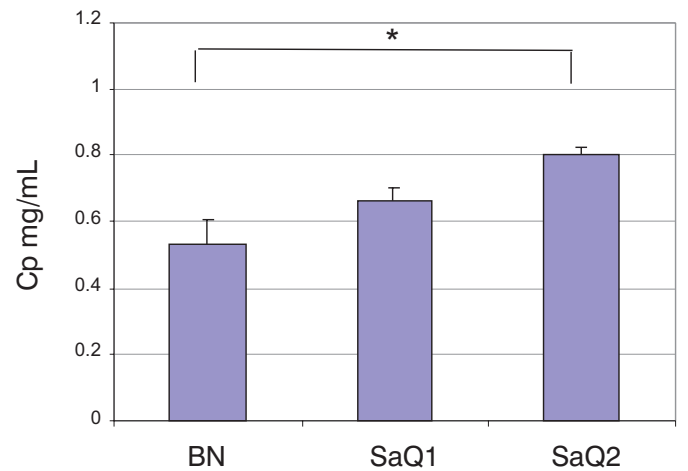


Acta Veterinaria (Beograd), Vol. 60, No. 2-3, 205-216, 2010.

Kovačević Filipović Milica et al.: Acute phase protein response

D

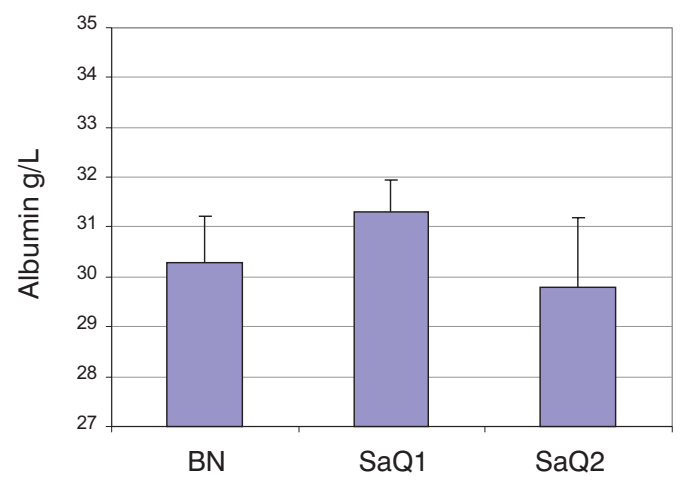

Figure 2. The concentration (mean $\pm S D$ ) of $A$ ) Serum amyloid $A(S A A)$; B) Haptoglobin $(\mathrm{Hp})$; C) Ceruloplasmin (Cp); D) Albumin in serum from cows with all quarter samples bacteriologically negative (BN group), one quarter infected with Staph. aureus (SaQ1 group) and two quarters infected with Staph. aureus (SaQ2 group)

Serum $\mathrm{Cp}$ concentration (Figure $2 \mathrm{C}$ ) increased with number of quarters infected and the significant difference between BN group and SaQ2 group was detected $(0.5 \mathrm{mg} / \mathrm{mL}$ versus $0.8 \mathrm{mg} / \mathrm{mL})$. Albumin concentration in the sera was within the reference range in all three groups of cows, although SaQ2 group of cows had lower concentration comparing with the first two groups of cows (Figure 2D).

The absolute number of total leukocyte, lymphocyte and neutrophil granulocyte in all groups was within the physiological range for dairy cows (Figure $3 \mathrm{~A}, 3 \mathrm{~B}$ and $3 \mathrm{C}$ ). Yet, we observed a significant fall in total leukocyte number in $\mathrm{SaQ} 1$ and SaQ2 cows that issued from decrease in both, lymphocyte and neutrophil granulocyte number (Figure 3B and $3 \mathrm{C}$ ).

A

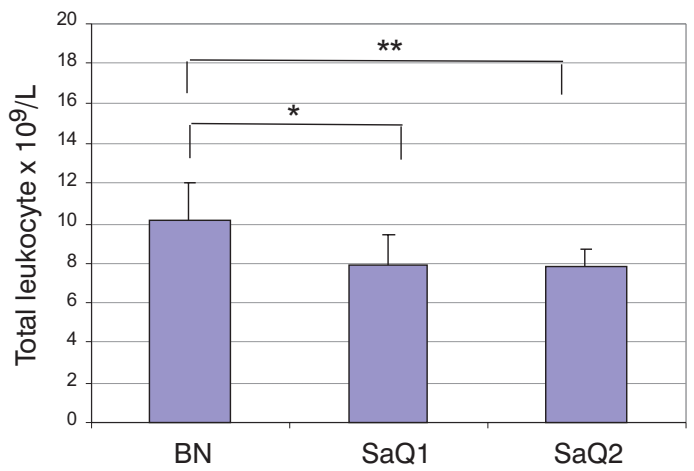


B

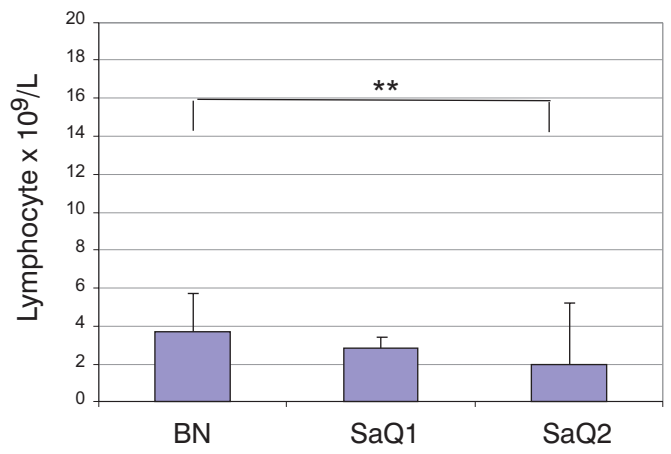

C

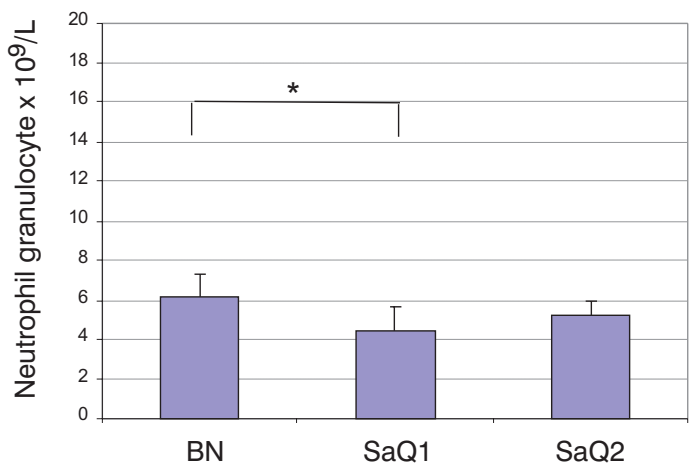

D

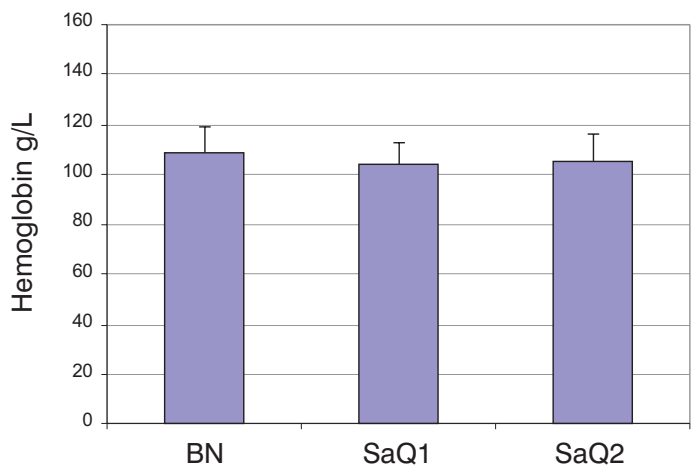

Figure 3. A) Total leukocyte; B) Lymphocyte; C) Neutrophil granulocyte and D) Hemoglobin concentration (mean $\pm \mathrm{SD}$ ) in serum from cows with all quarter samples bacteriologically negative (BN group), one quarter infected with Staph. aureus (SaQ1 group) and two quarters infected with Staph. aureus (SaQ2 group); The shaded areas on each figure respresent physiological range of this parameter for dairy cows according to Brun-Hansen et al. (2006) 
Hemoglobin concentration was in the physiological range in all three groups of cows (Figure 3D). Other hematologic parameters also were in the physiological range (data not shown).

\section{DISCUSSION}

In the present study it was demonstrated that the magnitude of local and systemic APPs reaction to Staph. aureus subclinical mastitis differed between animals having one or more infected quarters.

Milk findings suggested that a) bacteriologically negative quarter milk had very low SAA concentrations, b) quarter milk samples when only one quarter was infected with Staph. aureus had lower SAA concentration than quarter milk samples when two quarters were infected. Milk SAA concentrations paralleled SCC, lowest value being recorded in bacteriologically negative milk quarters $\left(0.04 \times 10^{6} / \mathrm{mL}\right)$ and highest in quarter milk samples from mammary glands with multiple quarters infection (25 times elevated SCC).

In our study the average SAA concentration in bacteriologically negative quarter milk was in the same, relatively wide reference intervals reported in literature (Eckersall et al., 2006; Lindmark-Mansson et al., 2005; Lechtolainen et al., 2004; Nielsen et al., 2004). These wide reference intervals are probably partly due 1. to inherited ability of individual cows to synthesize SAA (Jacobsen et al., 2004), 2. to sampling procedure (premilking or postmilking) and 3. to sample management (non skimmed, partially skimmed, skimmed milk or even whey samples) prior to SAA determination (Eckersall et al., 2001; Lechtolainen et al., 2004; Nielsen et al., 2004; Lindmark-Mansson et al., 2005; Eckersall et al., 2006). Our study was done with partially skimmed milk and results demonstrated that SAA was 70 times higher in quarter milk samples than baseline when one quarter was inflamed and about 120 times higher when two quarters were involved. The same magnitude of APP response was reported previously in experimentally (Eckersall et al., 2006; Jacobsen et al., 2005; Lechtolainen et al., 2004) or naturally occurring diverse intramammary infections (Eckersall et al., 2001; Nielsen et al., 2004; Lindmark-Mansson et al., 2005). Concerning its fast rise in milk after infection (Jacobsen et al., 2005) and elevation degree, milk SAA is the most sensitive local indicator of inflammation.

Our study also revealed that systemic APPs reaction to subclinical Staph. aureus mastitis was different depending on the number of quarters infected. None of the analyzed positive plasma APPs was significantly increased, nor albumin was decreased, when one quarter was infected. Cows that had two quarters infected had four times higher SAA, eight times higher $\mathrm{Hp}$ and 1.5 times higher $\mathrm{Cp}$ plasma concentration than the other two groups of animals. Comparable magnitude of plasma SAA and Hp increase was reported by Eckersall et al., (2006), during experimentally induced Staph. aureus infection of 3 mammary quarters, but much higher concentrations were reported when endotoxin (from $E$. coli) was used to challenge the mammary gland (Lehtolainen et al., 2004). Among APPs, $\mathrm{Cp}$ is not considered as a sensitive marker of inflammation in cows, but a large extent of tissue damage provoked during subcutaneous turpentine injection 
(Conner et al., 1998), endotoxin administration (Conner et al., 1989), clinical mastitis (Tabrizi et al., 2008) or theileriosis (Nazifi et al., 2009) stimulate its hepatic synthesis. On the contrary, pasterella infection (Conner et al., 1989), as well as subclinical mastitis (Tabrizi et al., 2008) did not have a substantial effect on plasma Cp concentration. Our finding demonstrated that even subclinical mastitis could influence $\mathrm{Cp}$ concentration - if multiple quarters were inflamed. Plasma albumin concentration decreased in multiple quarters' infected cows, but not significantly. It is evidenced that plasma albumin leaks in milk during mastitis (Phillippy and McCarthy, 1979). Moreover, albumin synthesis in the liver can be attenuated in favor of acute phase protein synthesis. According to our results, during Staph. aureus subclinical mastitis this potential plasma loss is not substantial and does not affect albumin plasma concentration significantly. According to normal hemoglobin concentration, disturbances of erytropoiesis due to chronic inflammatory disease have not been present. Also, the decreased but normal leukocyte range indicates that the rate of leukocytes lost through milk of inflamed quarters is well compensated by the bone marrow.

Altogether these findings are important because they show that Staph. aureus infection of one quarter provoked detectable local inflammatory response, but did not provoke a detectable systemic response. Multiple quarters' infection elicited a systemic response, as it could be seen by positive APPs rise. The systemic response was not of importance in order to interfere with albumin synthesis in the liver and to influence erythropoiesis.

The interesting phenomenon to be discussed is the higher magnitude of local tissue reaction when two quarters were inflamed. One possibility is the nature of infection: namely the strain (genotypes) of Staph. aureus itself (Dingwell et al., 2006) and number of Staph. aureus colony forming units (Eskersall et al., 2006) could both be of importance to the magnitude of inflammatory response. These likelihoods remain to be tested in future investigations. The other possibility could be deduced as follows: extensive systemic response in terms of plasma APP synthesis could influence APP concentration at the site of injury, namely the mammary gland (milk) itself. It was demonstrated that inflamed mammary gland epithelial cells enhance synthesis of specific milk SAA isoform and secret it in the milk (Weber et al., 2006). Also, the inflamed mammary gland is the site of plasma SAA exudation leading to the additional rise in concentration of SAA in milk (Jacobsen et al., 2005). It is possible to speculate that in our investigation, a significant rise in milk SAA concentration, when more than one quarter was infected, is due to additional exudation of very high plasma SAA. Further on, higher SCC in milk with higher SAA concentration could be related to SAA chemotactic capacity (Olsson et al., 1999).

In conclusion the magnitude of local and systemic APPs response in subclinical Staph. aureus mastitis depended on the number of quarters infected.

This research was supported by a grant from the Ministry of Science and Technology development of the Republic of Serbia, project No 20061-TR. 
Address for correspondence:

Dr Kovačević Filipović Milica

Faculty of Veterinary Medicine, University of Belgrade

Department of Patophysiology

11000 Beograd, Serbia

Bulevar oslobođenja 18

E-mail address: milkovac@yahoo.com

\section{REFERENCE}

1. Barkema HW, Schukken YH, Zadoks RN, 2006, Invited Review: The role of cow, pathogen, and treatment regimen in the therapeutic success of bovine Staphylococcus aureus mastitis, $J$ Dairy Sci, 89, 1877-95.

2. Brun-Hansen HC, Kampen AH, Lund A, 2006, Hematologic values in calves during the first 6 months of life, Vet Clin Path, 35, 182-7.

3. Conner JG, Eckersall PD, Wiseman A, Bain RK, Douglas TA, 1989, Acute phase response in calves following infection with Pasteurella haemolytica, Ostertagia ostertagi and endotoxin administration, Res Vet Sci, 47, 203-7.

4. Dingwell RT, Leslie KE, Sabour P, Lepp D, Pacan J, 2006, Influence of the genotype of Staphylococcus aureus, determined by pulsed-field gel electrophoresis, on dry-period elimination of subclinical mastitis in Canadian dairy herds, Can J Vet Res, 70, 115-20.

5. Djabri B, Bareille N, Beaudeau F, Seegers $H, 2002$, Quarter milk somatic cell count in infected dairy cows: a meta-analysis, Vet Res, 33, 335-57.

6. Eckersall PD, Young FJ, McComb C, Hogarth CJM, Safi S, Weber A et al., 2001, Acute phase proteins in serum and milk from dairy cows with clinical mastitis, Vet Rec, 148, 35-42.

7. Eckersall PD, Young FJ, Nolan AM, Knight CH, McComb C, Waterston MM et al., 2006, Acute phase proteins in bovine milk in an experimental model of Staphylococcus aureus subclinical mastitis, J Dairy Sci, 89, 1488-501.

8. Holmberg, CG, Laurell CB, 1951, Investigations in Serum Copper. III. Ceruloplasmin as an Enzyme, Acta Chem Scan, 5, 476-80.

9. International Dairy Federation, 1971, A monograph of bovine mastitis, Part I. Ann Bull (In Kieler Milchwirtschaftliche Forschungsberichte 1977, pp. 34).

10. Jacobsen S, Niewold TA, Kornalinalijnslijper E, Toussaint MJM, Gruys E, 2005, Kinetics of local and systemic isoforms of serum amyloid A in bovine mastitis milk, Vet Immunol Immunopath, 104, 21-31.

11. Lehtolainen T, Røntved C, Pyörälä S, 2004, Serum amyloid A and TNF alpha in serum and milk during experimental endotoxin mastitis, Vet Res, 35, 651-9.

12. Lindmark-Mansson H, Branning C, Alden G, Paulsson M, 2006, Relationship between somatic cell count, individual leukocyte populations and milk components in bovine udder quarter milk, Int Dairy J, 16, 717-27.

13. McDonald TL, Larson DR, Mack A, Weber A, 2001, Elevated extrahepatical expression and sectretion of mammary-associated serum amyloid A3 (M-SAA3) into colostrum, Vet Immunol Immunopath, 83, 203-11.

14. McPherson IG, Ecerard DW, 1972, Serum albumin estimation: Modification of the bromcresol green method, Clin Chim Acta, 37, 117-21.

15. Medzhitov R, 2008, Origin and physiological roles of inflammation, Nature, 454, 428-35.

16. Nazifi S, Razavi SM, Esmailnejad Z, Gheisari H, 2009, Study on acute phase proteins (haptoglobin, serum amyloid A, fibrinogen, and ceruloplasmin) changes and their diagnostic values in bovine tropical theileriosis, Parasitol Res, 105, 41-6.

17. Nielsen BH, Jacobsen S, Andersen PH, Niewold ThA, Heegaard PH-M, 2004, Acute phase protein concentrations in serum and milk from cows with clinical mastitis, with extramammary inflammatory conditions and clinical healthy cows, Vet Rec, 154, 361-5. 
18. Olsson N, Siegbahn A, Nilsson G, 1999, Serum Amyloid A Induces Chemotaxis of Human Mast Cells by Activating a Pertussis Toxin-Sensitive Signal Transduction Pathway, Biol Bioph Res Comm, 254, 143-6.

19. Pyörälä S, 2003, Indicators of inflammation in the diagnosis of mastitis, Vet Res, 34, 565-78.

20. Sears PM, Smith BS, English PB, Herer PS, Gonzalez RN, 1990, Shedding pattern of Staphylococcus aureus from bovine intramammary infections, J Dairy Sci, 73, 2785-90.

21. Tabrizi AD, Batavani RA, Rezaei SA, Ahmadi M, 2008, Fibrinogen and ceruloplasmin in plasma and milk from dairy cows with subclinical and clinical mastitis, Pak J Biol Sci, 11, 571-6.

22. Tolle A, Heeschen W, Hamann J, 1977, Fundamentals of a systematic control of subclinical bovine mastitis, Kieler Milchwirtschaftliche Forschungsberichte, 29, 3-103.

23. Uhlar CM, Whitehead AS, 1999, Serum amyloid A, the major vertebrate acute-phase reactant, Eur J Biochem, 265, 501-23.

24. Weber A, Weber AT, McDonald TL, Larson MA, 2006, Staphylococcus aureus lipotechoic acid induces differential expression of bovine serum amyloid A3 (SAA3) by mammary epithelial cells: Implications for early diagnosis of mastitis, Vet Immunol Immunopath, 79-83.

\title{
REAKCIJA PROTEINA AKUTNE FAZE KOD KRAVA SA SUBKLINIČKIM MASTITISOM IZAZVANIM STAPHILOCOCCUS AUREUS-OM
}

\author{
KOVAČEVIĆ FILIPOVIĆ MILICA, STEVANOVIĆ JELKA, STEVANOV PAVLOVIĆ MARIJA, \\ DEBELJAK MARTAČIĆ JASMINA, KNEŽEVIĆ MILIJANA, MIJAČEVIĆ ZORA \\ i BOŽIĆ TATJANA
}

\section{SADRŽAJ}

Lokalna i sistemska zapaljenjska reakcija predstavljaju kompleksne procese koji uključuju sintezu proteina akutne faze sa mnogobrojnim funkcijama u regulaciji samog zapaljenskog procesa. Cilj ovog rada je bio da se definiše lokalni i sistemski odgovor proteina akutne faze, koji je podstaknut prirodnom subkliničkom infekcijom mlečne žlezde sa Staph. aureus kod mlečnih krava, ali sa različitim brojem inficiranih četvrti. Mlečne krave $(n=30)$ u sredini laktacionog perioda su podeljene u tri grupe. U prvoj grupi su bile krave sa bakteriološki negativnim uzorcima mleka (BN grupa), u drugoj krave sa jednom četvrti vimena inficiranom sa Staph. aureus (SaQ1), dok su u trećoj grupi bile krave sa dve četvrti vimena inficiranim sa Staph. aureus (SaQ2). Uzorke mleka smo analizirali na sledeće pokazatelje zapaljenja: serum amiloid A (SAA) i broj somatskih ćelija (BSĆ). U uzorcima krvnog seruma su ispitivani SAA, haptoglobin (Hp), ceruloplazmin (Cp) i koncentracija albumina. Takođe je urađena kompletna krvna slika. BSĆ i SAA su bili najniži u mleku iz BN grupe i najviši u SaQ2 grupi. U uzorcima krvnog seruma SAA, Hp, Cp i koncentracija albumina bili su značajno viši samo u SaQ2 grupi u poređenju sa BN grupom. Broj leukocita kao i koncentracija haptoglobina su bili u fiziološkim granicama kod sve tri grupe krava. Ovi rezultati ukazuju da krave koje imaju subkliničku infekciju sa Staph. aureus u dve četvrti vimena imaju i jače izraženi sistemski odgovor proteina akutne faze nego krave kojima je inficirana samo jedna četvrt vimena čime je pokazano da opseg povrede tkiva ima uticaj na koncentraciju proteina akutne faze u serumu. 